

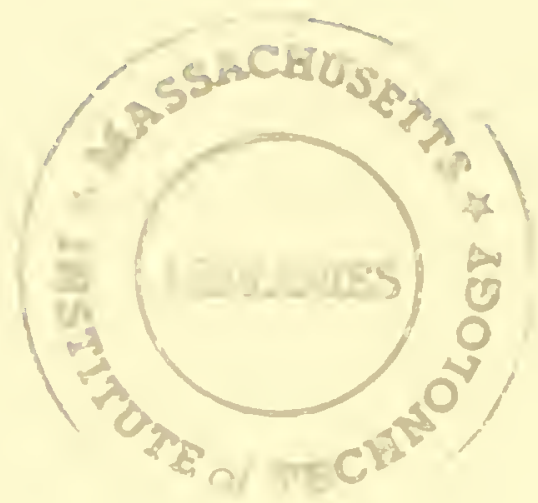






\section{HD28 \\ .M4 14 \\ no. 2514 .}

89

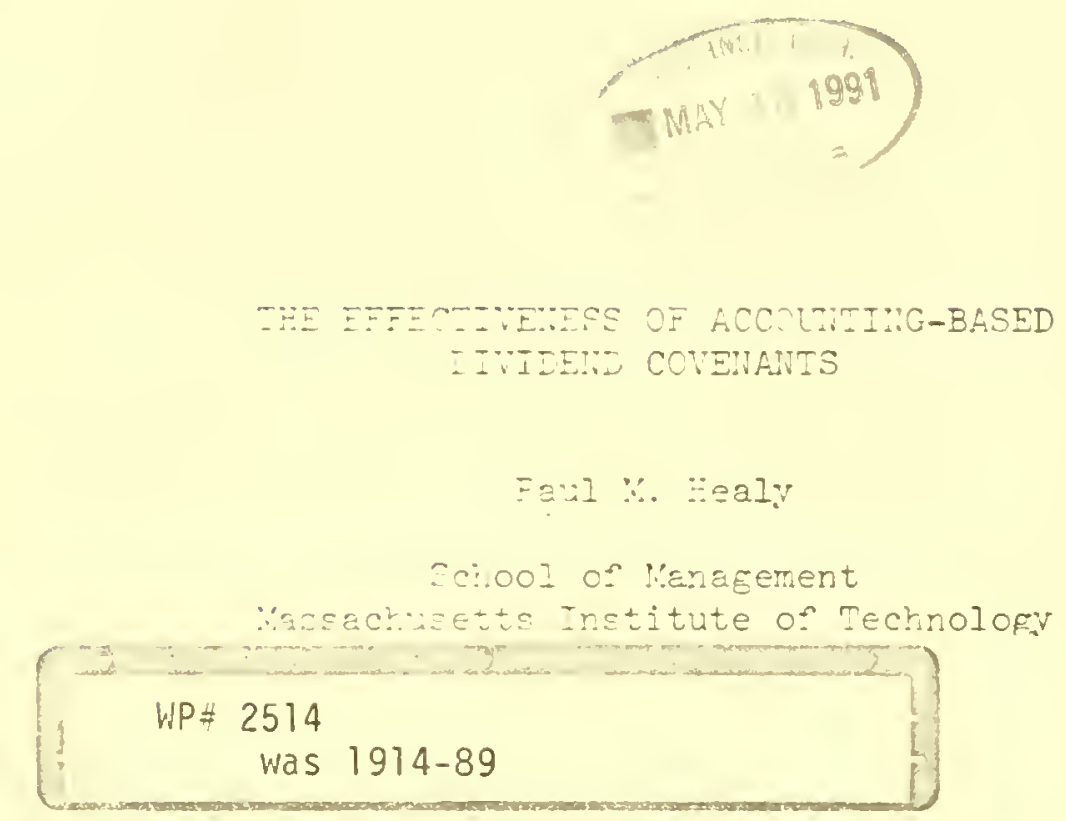


- 


\title{
THE EFFECTIVENESS OF ACCOUNTING-BASED DIVIDEND COVENANTS
}

\author{
Paul M. Healy \\ School of Management \\ Massachuselts Institute of Technology \\ Krishna G. Palepu \\ Graduate School of Business Administration \\ Harvard University
}

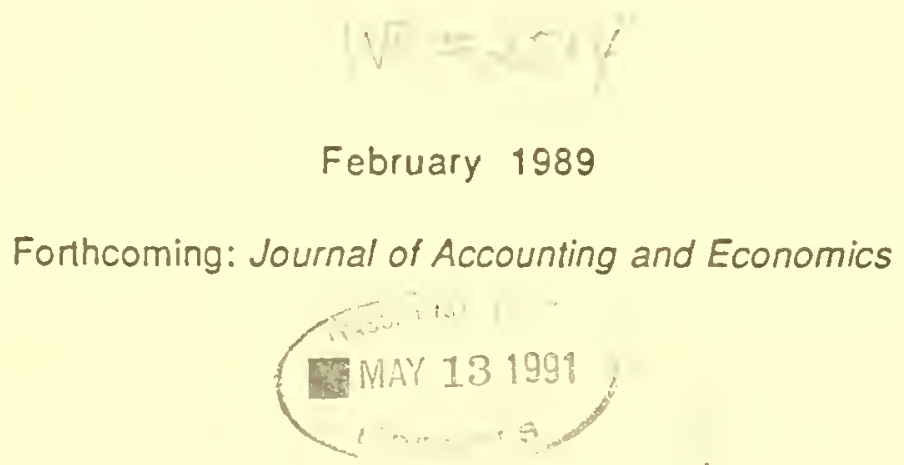

The paper has benefited from the comments of Joy Bagley, Bob Holihausen, Bob Kaplan, Katherine Schipper, Ross Walts, Karen Wruck, the conference participants at the University of Rochester, and seminar participanls at Duke University, the University of California at Los Angeles, and the Wharton School. We would like to thank Jeffrey Liu and Ken Hao for their research assistance and the Division of Research, Harvard Business School for funding the research. 



\section{THE EFFECTIVENESS OF ACCOUNTING-BASED DIVIDEND COVENANTS}

This paper examines whether firms that are close 10 violating their lending covenants make income-increasing accounting decisions 10 avoid cutting dividends. While firms close 10 their dividend restriction adopt income-increasing pension accounting changes, these appear to be motivated by cash management concerns. There is no evidence that these firms make other accounting changes to circumvent the dividend restriction. However, there is a substantial increase in the frequency of dividend cuts and omissions for these firms. The magnitude of the dividend cuts is related to the tightness of the dividend constraint. Thus despite the accounting flexibility available 10 managers, accounting-based covenants appear to be effective means for bondholders to restrict firms' dividend policies. 

DENEY

M.!.
MAY 131991
GEUL-1 


\section{INTRODUCTION}

Dividend restrictions, the most common covenant in debt contracts, are designed to reduce potential conflicts of interest between bondholders and stockholders. These restrictions define funds available for dividend payments in terms of accounting earnings, typically under generally accepted accounting principles (GAAP). Since there is considerable accounting discretion available under GAAP, managers can potentially circumvent dividend covenant restrictions, and avoid dividend cuts (to the detriment of bondholders) by increasing earnings through accounting decisions. This paper examines accounting and dividend policy changes in response 10 an increase in the tightness of the dividend covenant restriction to assess whether accounting earnings-based dividend covenants are effective means for bondholders to protect themselves by restricting managers from using dividend policy to transfer wealth 10 slockholders.

The results, based on a sample of 126 firms which were close 10 violating their dividend covenant restrictions during the period 1981-1985, indicate that there are no significant changes in firms' accounting methods surrounding the near-violation. While the sample firms adopt income-increasing pension accounting assumptions during the four years surrounding the near-violation of the dividend constraint, they appear to be motivated by cash flow considerations, rather than the increase in tightness of the dividend constraint. In contrast, in the year of the near-violation there is a substantial increase in the frequency of dividend cuts and omissions, persisting for several subsequent years. The magnitude of the dividend reductions is related to the degree of tightness of the dividend constraint, even after controlling for changes in earnings and operating cash flows. A small number of sample firms also restructure the debt that contains the binding dividend restriction. We therefore conclude that accounting decisions play only a limited role in sample firms' overall responses. Despite the accounting discretion available 10 managers, earnings-based dividend covenants appear 10 be 

effective means for bondholders 10 constrain firms' dividend policies.

The rest of the paper is organized as follows. Section two describes the dividend covenant restriction. Section three discusses the sample and the data. The accounting response results are presented in section four, and dividend and debt restructuring responses are reported in section five. The final section presents a discussion of the findings.

\section{DIVIDEND COVENANT RESTRICTIONS}

Covenant restriclions in debt contracts are designed to reduce the potential conflict of interest between bondholders and slockholders (see Jensen and Meckling (1976), Myers (1977), Smith and Warner (1979), Kalay (1982), and Leftwich (1983)). While debt contracts include a variety of accounting-based restrictions on the firm, dividend covenants are the most frequent. Duke and Hunt (1989) examine the debt covenants for a random sample of 187 firms from Moody's Industrial Manual, and report that 55\% of the sample have a dividend covenant, $35 \%$ have a working capital covenant, $28 \%$ have a debt-equity ratio covenant, and $18 \%$ have a stockholders' equity covenant.

Since stockholders (or managers appointed by them) control the firm, they have incentives to pursue dividend policies which transfer wealth from bondholders 10 stockholders. For example, shareholders have an incentive to deplete existing assets by paying out dividends, thereby reducing the collateral available to bondholders' in the event of default. This incentive is particularly severe when the firm is performing poorly. In rational debt markets, the price of debt reflects the probability of such opportunistic behavior. Managers and slockholders can reduce the resulting cost by precommitting to limit the level of future dividend payments. The high frequency of dividend covenants in debt contracts suggesis that bondholders consider this 

conflict to be important, and believe that the firms' managers will not cut dividends to protect bondholders' interesis without this covenant.

As Kalay (1982) reports, dividend covenants typically define an inventory of funds available for dividends (inventory of payable funds or IPF) over the life of the debt. The usual definition of the inventory for period $\mathrm{t}$ (Kalay (1982), and Watts and Zimmerman (1986)) is :

$$
I P F_{t}=k \sum_{\tau=0}^{t} E_{\tau}+\sum_{\tau=0}^{t} S_{\tau}-\sum_{\tau=0}^{t-1} D_{\tau}+F
$$

where, $E_{\tau}$ are earnings for period $\tau, k$ is a constant $(0 \leq k \leq 1), S_{\tau}$ is the proceeds from slock issues in period $\tau, D_{\tau}$ is dividends and share repurchases in period $\tau$, and $F$ is a fixed number. The formula implies that the inventory of payable funds depends on accumulated retained earnings and the amount of new stock issued since the date of the debt issue $(\tau=0) .1$

The following description of the dividend restriction faced by Gulf \& Western Industries, Inc. in a 1966 public debt issue illustrates the above formula:

(The) company may not pay cash dividend's or acquire capital slock in excess of consolidated net income after December 31, 1965; plus net proceeds from the sale of capital slock after such date, up to an amount not exceeding the amount expended after such date 10 purchase or redeem capital shares; plus $\$ 7,000,000$. (Moody's Industrial Manual, 1985, p. 436).

Moody's also reported that at July 31, 1984, Gulf \& Western had $\$ 329$ million of unrestricted retained earnings (or inventory of funds payable) available for dividends under the firm's most restrictive covenant. In 1984, the company paid $\$ 65.5$ million in cash dividends and used

1 Dividend payments are also constrained indirectly through covenants requiring the maintenance of a minimum level of working capital or a minimum net worth. This paper focusses only on direct dividend covenants. 

$\$ 170.4$ million for share repurchases.

Debt covenants typically use earnings computed under generally accepted accounting principles (GAAP) (see Smith and Warner (1979) and Leftwich (1983)). GAAP permits a variety of accounting policies to record the same economic event. Some covenants, especially in private lending agreements, make adjustments 10 GAAP 10 reduce management's discretion. However, debt covenants generally do not constrain firms' choices of accounting policies within GAAP.2

Watts and Zimmerman (1986) hypothesize that when a firm is close to exhausting its inventory of payable funds, managers have an incentive to exploit the accounting discretion available under GAAP and make income-increasing accounting decisions to avoid reducing dividend payments. A few siudies test this hypothesis by examining the relation beiween dividend covenant restrictions and firms' accounting choices. Bowen, Noreen and Lacey (1981), and Daley and Vigeland (1983) report that firms that capitalize interest, and research and development expenses have lower inventories of funds available for dividends than firms that expense these items. In contrast, Holthausen (1981) finds no relation between the inventory of payable funds and depreciation accounting changes. A number of other studies use the debvequity ratio as a proxy for tightness of covenant restrictions and conclude that the probability of a firm selecting income-increasing accounting procedures is positively related to

2 Leftwich (1983) argues that it is optimal to allow managers some flexibility in the choice of accounting policies. 

closeness to covenant constraints. ${ }^{3}$

The above evidence suggests that dividend covenants based on accounting earnings may not be an effective means of protecting bondholders' interests. 4 The intent of dividend covenants is to induce managers of firms that are close to their constraint to cut dividends or renegotiate the debt, rather than 10 change accounting policies. This paper provides descriptive evidence on the relative frequencies of accounting policy changes, dividend reductions, and debt renegotiations for a sample of firms that are close to their dividend constraint. The findings are useful in assessing whether accounting-based dividend covenants are effective means for bondholders to restrict managers from using dividend policy to transfer wealth 10 stockholders.

\section{SAMPLE SELECTION AND DATA}

The sample comprises firms that experience a sharp increase in the tightness of their dividend constraint during the period 1981 10 1985. The inventory of payable funds (unrestricted retained earnings) under the most restrictive dividend covenant, which is reported in firms' financial statement footnotes, and on the Standard and Poor's Compustat data base, is used in the sample selection. Tightness of the dividend constraint is estimated by the ratio of funds available for dividends in a given year 10 dividends in the previous year. Funds available for dividends are defined as unrestricted retained earnings at year end plus common and preferred cash dividends paid and stock repurchases during the year. These funds represent

3 See, for example, Deakin (1979). Dhaliwal (1980), Bowen, Noreen and Lacey (1981), Zmijewski and Hagerman (1981), Dhaliwal, Salamon and Smith (1982), Lilian and Pastena (1982), and Daley and Vigeland (1983).

4 A recent study of accounting changes by Lilien, Mollman, and Pastena (1988) concludes that despite increased regulation of accounting choices by the FASB and SEC, managers are able to modily reported income through accounting changes. 

the maximum dividends and stock repurchases that a firm can pay during the year without violating its dividend constraint or issuing new equity. The ratio of this variable to the previous year's common and preferred cash dividends and slock repurchases is the number of years that a firm can maintain its level of dividends (and repurchases) without additional future earnings or common slock issues. If this number of years is less than two, a firm is defined to be close 10 its dividend constraint. 5

To select the sample, we first identify all firms that pay cash dividends in 1979 from the 1986 Compustat Industrial and Research files. For these firms we compute the number of years of unrestricted retained earnings available for dividends in 1980 and discard firms with less than two years. For the remaining firms we monitor the number of years of unrestricted retained earnings for 1981 to 1985. A firm is included in the sample if the number of years of unrestricted retained earnings falls below two in one of these five years. The sample thus comprises all firms for which the dividend constraint was not close to binding in 1980 , but became close to binding in one of the five subsequent years. One hundred and thirty-three firms are identified from this process. The year in which a firm first comes close to breaching its dividend covenant is defined as the event year (year 0 ). Annual reports for years $-1,0,1$, and 2 are collected for the sample firms. The final sample comprises the 126 firms for which reports are available6. The frequency of near-violations for these firms by year is relatively

5 Selecting firms with less than two years of funds available lor dividends is somewhat arbitrary. A cutolf of two years is selected to tradeoll sample size, and therefore the power of the tests, with the costs of data collection. Data collection costs are significant in this study since data are largely hand-collecled through a delailed reading of companies' annual reports.

6 The debt lootnotes in these companies tinancial statements discuss the dividend and other restrictive covenants facing the firm. The most common restriction discussed is the dividend constraint, which delines unrestricted retained earnings available for dividends. Working capital covenants, which restrict cash available for dividend payments, are also discussed but there is no 

evenly distributed across the sample period: $20 \%$ in $1981,30 \%$ in $1982,16 \%$ in $1983,14 \%$ in 1984 and $20 \%$ in 1985 .

Table 1 presents descriptive statistics on the number of years of unrestricted retained earnings available for dividends in years -5102 for the sample firms and their industry medians. ${ }^{7}$ In years -5100 this variable is defined as unrestricted retained earnings at year end plus cash dividends and stock repurchases, divided by cash dividends and stock repurchases for the prior year. In years 1 and 2 the number of years is defined as unrestricted retained earnings at year end plus cash dividends and slock repurchases, divided by cash dividends and stock repurchases for year -1.8

For years $-510-1$, the sample firms have on average seven to nine years of unrestricted retained earnings available for dividends, similar to their industries. The mean number of years for the sample firms falls sharply to 1.2 in year 0 . In contrast, the sample firms' industries do not experience a decline in funds available for dividends in year 0 . In the Iwo subsequent years, there is no further deterioration in sample firms' funds available for dividends. The sample firms thus experience a sudden increase in the tightness of their dividend

indication for our sample firms that they consider violation of these constraints to be imminent. Using the footnote information in the annual reports, we verify the value of unrestricted retained earnings reported by Compustat.

7 Industry medians are calculated lor all Compustat Industrial and Research firms that pay dividends and are in the same lour-digit Standard Industry Code as the sample firms.

8 Defined this way, the variable measures the number of years of petained earrings available for dividends absent a change in dividend policy subsequent to the near-violation of the dividend constraint. 

constraint, which is unmatched by their industry counterparts. 9

The sample firms can take a number actions in anticipation of, and following, the dramatic decline in their dividend-paying abilities. They can make accounting decisions to bolster income. Alternatively, they may reduce dividend payments, and/or renegotiate the debt that has the binding dividend constraint. To analyze firms' responses to the dividend constraint, we read the management's report, the financial statements, and footnotes from the annual reports of each sample firm in years -1 to 2. From these sources we collect data on: (i) accounting procedures used during year -2 ; (ii) changes in accounting procedures in years -1 102 ; and (iii) dividend covenant waivers, debt retirements or restructurings in years -1102 . We also collect the following data from Compustat for years -5 to 2: (i) earnings, operating cash flows, non-working capital accruals (depreciation and deferred taxes), and working capital accruals (changes in receivables, payables, and inventory) as a percentages of sales and assets; (ii) common dividends per share; (iii) earnings and operating cash flows per share; and (iv) beginning of year stock price.

To construct a population benchmark, we collect data on accounting method changes from 1980 to 1986, and accounting policies for 1979 to 1983 from Accounting Trends and Techniques (hereafter ATT). ATT is published annually by the American Institute of Certified Public Accountants from a survey of the financial reports of 600 major public corporations. The firms surveyed by ATT are typically larger than those in our sample. Sixty-four percent of the sample firms have annual revenues of less than $\$ 500$ million compared to $31 \%$ for ATT.

9 We also examine unrestricted retained earnings for the sample firms in years -5 to -2 to determine whether the dividend constraint had been binding prior to the sample period. None of the firms had less than one year of funds available for dividends in these years. Two firms in year -5 , one firm in year -4, and no firms in year -3 and -2 had less than two years of funds available for dividends. Thus, the dividend constraint was not binding in the few years prior to the lest period. 
Further, only $12 \%$ of our sample have revenues greater than $\$ 2$ billion, compared to $36 \%$ for ATT. Earlier studies find that there is a negative relation between the likelihood that a firm selects income-increasing accounting procedures, and size (see Watts and Zimmerman (1986) for a summary of these studies). The size difference between our sample and the ATT population therefore biases our tests in favor of finding that the test firms make income-increasing accounting decisions relative to the ATT firms.

\section{ACCOUNTING DECISIONS AND DIVIDEND COVENANT RESTRICTIONS}

In this section we examine whether firms make accounting decisions in response to an increase in the tightness of their dividend covenant constraint. If firms already selected all available income-increasing accounting methods in prior years, they may have no further degrees of freedom available to respond to the increased tightness of the constraint. Therefore, we first analyze accounting procedures selected two years prior to the increased tightness of the dividend constraint. Next, we examine changes in accounting procedures in years -1 to 2 . Finally, since managers can also influence reported earnings through changes in accrual estimates, we also investigate accruals in these years.

\subsection{Accounting Procedure Choices}

In table 2 we tabulate the frequency of accounting procedure choices for the test firms in year -2. The accounting procedures examined are: depreciation methods, inventory pricing, extent of LIFO use, investment tax credit method, amortization period for intangibles, amortization period for pension prior period service costs, and pension rate of return assumptions. 10 Where available, we also report the frequency of choices made by the ATT firms.

10 The frequencies for depreciation, inventory, and investment tax credit do not add $10100 \%$ since some firms use more than one mothod. For example, some firms use both LIFO and FIFO, and are therefore included in both categories. 

A two-tailed Binomial test is used to compare the frequencies for these samples.

The test results, reported in Table 2, provide some evidence that the test firms are more likely 10 use income-increasing accounting procedures than the ATT firms in year -2. While most firms use Straight-Line depreciation, where there are multiple methods in use, the test firms are more likely to use the Units of Production, and less likely to use Accelerated methods than the ATT firms. Similarly, where multiple inventory accounting methods are used, the test firms have lower frequencies of LIFO and Average Cost than the ATT firms. A higher proportion of test firms use the Flow-Through method of Invesiment Tax Credit accounting, and amortize their intangibles over 40 years. These results should be interpreted with caution. As noted earlier, the test firms are on average smaller than the ATT firms. Therefore, the documented differences could be size-related rather than due to the differences in nearness to the dividend constraint.

There appear to be several areas where the sample firms have opportunities to change accounting methods 10 increase earnings. For example, many of the test firms use LIFO or Average Cosi, and may be able to increase earnings by changing to FIFO. Also, a number of test firms could increase the period used to amortize pension prior period service costs to the maximum allowed, or increase the pension rate of return assumptions. Both inventory and pension changes are likely to increase reported income. However, the inventory changes may entail higher tax payments, whereas the pension changes can reduce cash oullays by reducing funding requirements. In addition, some of the sample firms may be able 10 increase reported earnings through changes in depreciation and goodwill amortization methods. 



\subsection{Changes in Accounting Procedures}

To test whether firms that are close to their dividend constraint are more likely to change accounting procedures, we examine the frequency of reported changes by the sample firms during years -1102 . Voluntary changes examined include changes in pension accounting assumptions and/or cost methods, LIFO adoptions or extensions, other inventory changes, depreciation method changes, changes in depreciable lives, and Investment Tax Credit method changes. We also examine mandatory accounting changes since firms have discretion over the timing of their adoption. The mandatory changes relevant to the sample period include SFAS 43 (compensated absences), SFAS 52 (foreign currency translation), and SFAS 87 and 88 (pension accounting). To provide a population benchmark, the frequency of voluntary and mandatory accounting changes during these years are also reported for the ATT firms." A twotailed Binomial test is used to assess whether the frequency of changes for the test firms differs significantly from that for the ATT population.

Positive accounting theory predicts that, given an increase in the tightness of the dividend constraint and the potential cost that imposes on stockholders, managers of the test firms are likely 10 switch accounting methods to avoid being forced to cut dividends. The frequency of voluntary accounting changes in years -1 to 2 is therefore expected to be higher for the test firms than for the ATT firms. The timing of mandatory accounting changes is also likely to differ across these samples.

The results of the analysis are reported in Table 3. With the exception of changes in pension assumptions and/or cost methods, the frequency of voluntary accounting changes by the

11 ATT frequencies are computed for each sample firm in years - 1 to 2 using survey data from the corresponding calendar years. Table 2 reports the means of these frequencies. 

test firms is very small, and not different from the ATT benchmark.12,13 A significant proportion of the sample and ATT firms change their pension assumptions in each of years -1 to 2. However, the test firms' frequencies in year $0(33 \%)$, and year $1(37 \%)$ are both significantly larger than the ATT frequencies. The results of adoptions of mandated accounting methods are reported in Panel B of Table 3. There is no significant difference between the proportion of test firms and the ATT firms adopting these methods in the sample years. This indicates that the test firms do not behave differently from the ATT firms regarding the timing of these adoptions.

While the above results indicate that the change in closeness to the dividend constraint is in general not accompanied by changes in accounting methods, there are individual cases of firms making significant changes in their accounting policies during the sample period. For example, Raymark Corporation adopled Straight-Line depreciation in year -1 (increasing net income by $\$ 229,000$ ), changed pension actuarial assumptions in year 0 (increasing net income by $\$ 383,000$ ) and adopted FIFO in year 2 (increasing earnings by $\$ 5,951,000$ ). While it is possible that the above accounting changes (perhaps combined with less visible accrual policies) were motivated by the increased probability of contract breach, Raymark is an

12 Since a LIFO adoption or extension change typically decreases reported earnings, we would expect the frequency of changes to be lower for the lest firms than the ATT sample. We are unable to reject the hypothesis that there is a difference in the frequency of these changes for the two samples.

13 Table 2 indicates that ATT firms are more likely to have chosen Accelerated depreciation and the Doforral ITC method at the beginning of year -1. They therefore have more opportunities than the test firms to switch to income-increasing alternatives in subsequent years. We repoat the tests in Table 3 after adjusting for these differences. Of the test firms that could have switched to StraightLine depreciation, only $12 \%$ switch in years -1 to 2 . In comparison, $17 \%$ of the ATT firms that could have switched did so in these years. For the ITC, $10 \%$ of the lest firms and $22 \%$ of the ATT firms that could have switched to the Flow Through method did so in years -1 to 2. There is no evidence that, after controlling for differences in accounting flexibility for the two groups, the lest firmis have a higher frequency of income-increasing accounting changes than the AT firms. 
isolated case among the 126 sample firms.

\subsection{Further Evidence on Pension Accounting Changes}

The evidence in section 4.2 indicates that firms that are close to their dividend constraint are more likely to change pension accounting methods than the ATT sample. In this section we investigate these changes further. Panel A of Table 4 provides descriptive statistics on the frequency of different types of pension changes for the sample firms. The most frequent income-increasing change is in the rate of return assumption. In year $-19 \%$ of the sample firms increase the rate of return used to calculate the pension expense. The proportion is $27 \%$ in year $0,17 \%$ in year 1 , and $18 \%$ in year 2 . The second most frequent change is in actuarial assumptions. The percentage of the firms making these changes ranges from 4 to $10 \%$ per year. Changes in the amortization period for prior service costs are rare.

To assess the economic significance of the pension changes, we collect information on their effect on reported earnings for each firm that announced an accounting change. A large number of these firms report that the accounting change has no material effect on earnings $(28 \%, 60 \%, 50 \%$, and $62 \%$ in years -1 to 2 respectively). Panel B of Table 4 reports summary statistics on the income effect of pension changes for all firms that change their pension methods, and for those that disclose that the pension changes have a material effect on earnings. 14 The effect of the changes on after-tax earnings are deflated by dividends in year 1. This ratio measures the effect of the accounting change on the number of years of unrestricled retained earnings available for dividends.

14 The income effect of pension changes is assumed 10 be zero for firms that report that the effect is immaterial. The average effect reported in Table 3 for all pension changing firms is therefore likely to be understated. 
For all pension accounting change firms the median earnings effect in year -1 is $6 \%$ of dividends, and zero in the three subsequent years. The largest mean earnings effect is $34 \%$ and occurs in year 0 . In the remaining years the mean ranges from $8 \%$ to $18 \%$. The small median values suggest that for most of these firms, pension changes do not have a significant effect on dividend restrictions. However, there is evidence that the accounting changes have a significant effect for a few firms. The mean earnings effect for firms that disclose that the pension changes have a material effect on earnings is $83 \%$ of dividends in year 0 . There are five firms for which the earnings effect is greater than $50 \%$ of year -1 dividends. These are PSA Inc. (55\%), GAF Corp. (72\%), Gates Learjet Corp. (75\%), Portec Inc. (158\%), and Vertipile Inc. $(920 \%) .15$ The mean effect in the other years ranges from $12 \%$ to $35 \%$.

The above pension results indicate that: (i) the sample firms have a relatively high frequency of pension accounting changes in years -1 102 ; and (ii) for a few firms the pension change has a significant effect on the tightness of the dividend constraint. This evidence is consistent with the hypothesis that sample firms' pension accounting changes are motivated by dividend covenant considerations. However, there is a competing explanation. A reduction in pension expense, from changing pension assumptions, not only increases reported earnings but also decreases cash outflows. If the sample firms experience declines in operating cash flows, the pension changes may also be motivated by cash management concerns, rather than the tightness of the dividend covenant per se.16

15 Of these firms, two omitted common dividends in year 0 , two decreased their dividends, and one firm maintained its dividend.

16 Evidence presented later in the paper shows that the sample firms have lower operating cash flows than their industries in years 0 and 1 . 

To examine the relation between the earnings effect of pension accounting changes and the closeness to the dividend constraint after controlling for changes in operating cash flows, we estimate the following regression:

$$
P E F F_{j t}=B_{0}+B_{1} \Delta C F_{j t}+B_{2} D R_{j t}+\varepsilon_{j t}
$$

where, PEFF $\mathrm{jt}$ is the change in net income per share (cash flow per share) from the pension accounting changes as a percent of the stock price at the beginning of the year; $\triangle C F_{j t}$ is the change in operating cash flows per share excluding the effect of the pension change also as a percent of the stock price at the beginning of the year; $D R_{j t}$ is the number of years of unrestricted retained earnings available for dividends; and $\mathrm{j}$ and $\mathrm{t}$ represent firms and years respectively. 17 If pension accounting changes are motivated by cash management concerns, $B_{1}$ will be negative, whereas if they are motivated by dividend covenant considerations, $B_{2}$ will be negative.

Equation (1) is estimated for firms that make a pension accounting change using data in the year of the change. The results are presented in Table 5. The estimated coefficient for the cash flow variable $\left(B_{1}\right)$ is -0.025 . Although this value is relatively small, it is significant at less than the $5 \%$ level. The coefficient for the dividend restriction $\left(B_{2}\right)$ is insignificant at the

17 Operating cash flows before the effect of pension changes are Net Income + Depreciation + Deferred Income Taxes. Changes in Inventories and Recoivables + Changes in Payables - Afler-lax Change in Pension Expense due to the Accounting Change. 

$10 \%$ level. 18 These results suggest that the pension accounting changes are motivated by cash management considerations, rather than the dividend constraint.

We also estimate a number of alternative specifications of equation (1). First, we expand the sample to include all sample firms, rather than just the pension-changing firms, using data for years -1102 . Second, we include the level of cash and marketable securities as an additional independent variable. Third, we reconstruct the dividend restriction variable as a dummy variable, taking the value one if the number of years of funds available for dividends is less than two, and zero otherwise. The results are similar to those reported in Table 5. The estimated coefficient for the deflated change in cash flow $\left(B_{1}\right)$ is negative and significant, and the dividend restriction coefficient $\left(B_{2}\right)$ is insignificant.

There is thus no evidence that the dividend constraint influences the pension changes. Even though the sample firms make pension accounting changes in years surrounding the increase in tightness of the dividend constraint, it is not possible 10 attribute these to the dividend constraint itself.

\subsection{Accrual Management Decisions}

Changing accounting methods is but one means of managing reported earnings to reduce the probability of violating a dividend constraint. Managers can also select accruals that accelerate revenues or defer expenses. Accruals are less visible than method changes and are

18 Specification tests are conducted to assess whether the residuals are homoskedastic (see White (1980)), and normally distributed. We cannot reject the hypotheses that the residuals are homoskedastic and normally distributed at the 0.05 level. Belsley. Kuh and Welsch (1980) diagnostics for the effect of extreme observations on the coefficients, and for multicollinearity indicate that the reported estimates are not influenced by extreme observations, and that the independent variables are not collinear. 

therefore more likely to be used to manage earnings. Of course, their low visibility and the difficulty in specifying an accruals expectations model also increases the difficulty for the researcher to detect earnings management. To test whether managers use accruals to reduce the probability of breaching dividend constraints, we examine accruals, earnings and cash flows in years surrounding the increased tightness of the dividend constraint.

Panel A of Table 6 reports median values of operating cash flows, non-working capital accruals, working capital accruals, and earnings as percentages of sales for the sample firms in years -5 to 2.19 Panel $B$ presents medians of industry-adjusted ratios, computed as the difference between ratios for the sample firms and their industry medians.20 The sample firms experience significant declines in operating cash flow ratios relative to their industries in years -1 and 0 , and outperform their industries the following year. In years -1 to 2 working capital accruals fall sharply, and non-working capital accruals are relatively constant. Earnings, the sum of cash flows and accruals, therefore experience even greater declines in these years than cash flows. Hence, there is no prima facie evidence that managers use accruals to increase earnings in years surrounding the increased tightness of their dividend constraint.21

19 Working capital accruals are Changes in Receivables and Inventories - Changes in Payables. Non-working capital eccruals are Depreciation + Doferred income Taxes. The results presented in Table 6 are for accruals doflated by sales. We replicate the analysis using book values of assets rather than sales as a deflator, and the conclusions are unchanged.

20 Industry median ratios are computed for all Compustat Industrial and Research firms that pay dividends prior to year 0 , and are in the same four-digit SIC industry as the sample firms.

21 These conclusions are based on a random walk expectation model for accruals. Since there is no theoretical expectation model of accruals, this model is ad hoc. The findings should therefore be interpreted with caution. 


\subsection{Effect of Sample Selection on Results}

It is possible that the findings in sections 4.1 to 4.4 are influenced by a sample selection bias. If managers anticipate problems with their dividend covenants and have accounting flexibility, they may reduce the probability of covenant violation by changing accounting policies. In the extreme, when the sample selection requires firms to violate the dividend restriction, companies that exercised their accounting flexibility to circumvent the dividend covenant will be excluded. Only firms that have little accounting flexibility will be sampled and they will show no unusual number of accounting changes.

The sample in this paper consists of firms with iess than two years of unrestricted retained earnings and therefore contains some firms that have violated their dividend covenant in year 0 . If these firms have no accounting flexibility in that year, their inclusion in the sample will bias the results against finding accounting responses to an increase in the probability of a covenant violation. To address this issue, we repeat the analysis in sections 4.1 10 4.4 using only firms which do not violate the dividend covenant in year 0 (that is, firms with more than one year but less than two years of funds available for dividends). The results for this subsample are similar 10 those for the full sample, indicating that the sample selection bias is not important.22 We also believe that our results are not driven by sample selection bias because Holthausen (1981) uses a different sample selection procedure and arrives at the same results.

22 Wo also repoat the analysis for firms that cut dividends per share in any of years 0 to 2 , and for firms that increase or maintain their dividend rate in these years. There are no significant differences in accounting changes in years -1 to 2, and in the accounting choices in year -2 for the two subsamples. 
5. Dividend and Debt Renegotiation Responses to Dividend Constralnt Violation

\subsection{Dividend Change Responses}

If dividend covenants are effective means for bondholders to regulate firms dividend policies, firms experiencing sudden increases in the tightness of the constraint are likely to be forced to cut dividends. To test this hypothesis we examine the frequencies with which the sample firms increase, decrease, omit, and pay constant common dividends per share in years 4 to 2. Firms that are classified in the increase, decrease, and constant dividend categories pay non-zero dividends. Firms are included in the omit category each year they pay zero dividends. As a benchmark, we compute mean industry frequencies for these categories as follows. For each sample firm, the frequency of dividend changes is computed in years -4 to 2 for all Compustat Industrial and Research firms that pay dividends (preferred and/or common) and are in the same four-digit SIC industry. Cross-sectional means of these frequencies are then computed.

Table 7 reports the frequency of changes in per share common dividends for the sample firms and mean frequencies for their industries in years -4 to 2. In each of the four years prior to the increased tightness of the dividend constraint a majority of the sample firms as well as their industries increase common dividends per share. However, in year 0 the pattern of dividend changes for the sample firms diverges markedly from their historical pattern. In this year, the incidence of dividend increases for the sample firms falls from $57 \%$ to $20 \%$, and the frequency of dividend decreases or omissions goes up from $15 \%$ to $56 \%$. While there is also an industry-wide change in the frequency of dividend changes in this year, the magnitude is less dramatic: increases fall from $61 \%$ to $49 \%$, and decreases and omissions rise from $13 \% 1023 \%$. This pattern of dividend changes for both the sample firms and their industries persists for at least two further years. The results therefore indicate that for many firms the change In 
closeness to the dividend constraint is associated with a major change in dividend policy.

The decreases in sample firms' dividends in years 0 to 2 coincide with the increased tightness of their dividend constraints as illustrated in Figure 1. However, as documented in Table 6, the sample firms also experience a decline in reported earnings in these years. Since prior research (see Fama and Babiak (1968)) indicates that current and lagged earnings declines tend to be accompanied by dividend decreases, it is possible that the changes in sample firms' dividends are due to their poor performance rather than increased lightness of the dividend constraint. To examine the relation between dividend changes and dividend restrictions after controlling for earnings changes, we estimate the following regressions:

$$
\begin{aligned}
& \Delta D^{\prime} V_{j t}=B_{0}+B_{1} \Delta E A R N_{j t}+B_{2} D R_{j t}+\mu_{j t} \\
& \Delta D I V_{j t}=B_{0}+B_{1 j} \Delta E A R N_{j t}+B_{2} D R_{j t}+\mu_{j t} \\
& \Delta D I V_{j t}=B_{0}+\sum_{k=1}^{5} B_{k} \Delta E A R N_{j, t-k+1}+B_{2} D R_{j t}+\mu_{j t}
\end{aligned}
$$

$\triangle D I V_{j t}$ is the change in common dividends per share in year $t$ for firms $j$ as a percent of the stock price at the beginning of the year; $\triangle E A R N_{j t}$ is the change in earnings per share as a percent of the stock price at the beginning of the year; and $D R_{j 1}$ is the number of years of unrestricted retained earnings available for dividends in year t. Prior research suggests that the earnings coefficients will be positive. If dividend constraints have an effect on dividend policy, the dividend restriction coefficient will be positive.

The coefficients in equations (2) to (4) are estimated using data for all sample firms in 

years -4 to 2. Equation (2) assumes that the relation between earnings and dividend changes is constant across firms, and that only current earnings changes are important. These two assumptions are relaxed separately in equations (3) and (4). The earnings coefficients are allowed to vary across firms in equation (3) and four years' lagged earnings changes are included in equation (4).23

The regression results are presented in Table 8.24 In equation (2) the earnings coefficient is 0.014 and significant at the $1 \%$ level, confirming prior findings that there is a positive relation between earnings and dividend changes. The dividend restriction coefficient is 0.1 , also significant at the $1 \%$ level. Therefore, after controlling for the effect of earnings on dividend changes, there is a positive relation between the number of years of unrestricted retained earnings available for dividends and the magnitude of the dividend change. Equation (3) relaxes the assumption that the earnings coefficients are the same across the sample firms. The mean earnings coefficient is 0.017 , significant at the $1 \%$ level. An F-test indicates that the earnings coefficients differ across firms, inconsistent with the assumption in equation (2). However, relaxing this assumption does not change the magnitude or the significance of the dividend constraint coefficient.

23 We also estimate several other models. First, we estimate models with lagged earnings changes for one, two and three prior years but do not present the results here for brevity since they do not change the conclusions presented in the text. Second, we estimate equation (2) allowing the intercept to vary across firms. An F-test indicates that intercept terms do not vary across firms.

24 Specification tests are conducted to assess whether the residuals are homoskedastic (se日 White (1980)), and normally distributed. We cannot reject the hypotheses that the residuals are homoskedastic and normally distributed at the 0.05 level. Belsley, Kuh and Welsch (1980) diagnostics for the effect of extreme observations on the coefficients, and for multicollinearity indicate that the reported estimates are not influenced by extreme observations, and that the independent variables are not collinear. 

We also estimate a number of alternative specifications of equation (2). First, we include the change in operating cash flows, and the level of cash and marketable securities as additional independent variables. Second, we reconstruct the dividend restriction variable as a dummy variable, taking the value one if the number of years of funds available for dividends is less than iwo, and zero otherwise. The conclusion that the dividend restriction variable is highly significant is unchanged.

One explanation for the significant coefficient on the dividend restriction variable in equations (2) and (3) is that it captures the effect of lagged earnings changes which are omitted from these models. Equation (4) provides evidence contrary to this. The estimated coefficients indicate that dividend changes are related not only to current earnings changes, but also to changes in three prior years. 25 However, the introduction of the lagged earnings variables does not alter the magnitude of the coefficient on the dividend restriction variable, which is still significant at the $1 \%$ level. Further, since dividend changes are not related to earnings changes four years prior to the current year, it is unlikely that the dividend restriction variable is proxying for lagged earnings from earlier years.

The above results indicate that a large number of sample firms reduce their dividends when their dividend covenants become more restrictive. These dividend cuts are in part attributable to earnings declines. However, after controlling for the earnings' effect, there is a significant relation between the tightness of the dividend constraint and the magnitude of dividend cuts. Therefore, accounting-based dividend covenants appear to be effective in

25 Equation (4) does not allow the earnings coefficients to vary across firms since we do not have sufficient time-series observations per firm. 

restricting firms' dividend policies. 26

\subsection{Debt Renegotiation Responses}

In addition to reducing dividends, a number of the sample firms restructure the debt that contains the binding restriction. The debt restructuring responses include obtaining a waiver of the covenant, retiring the debt, amending the lending agreement, and/or issuing new equity to increase unrestricted retained earnings. The frequencies of these responses are shown in Table 9.27 In years -1 and 0 the most frequent response is to obtain a waiver of the covenant $(3.3 \%$ of the sample in year-1 and $6.5 \%$ in year 0 ), usually for preferred dividends. In the two subsequent years, the most frequent response is to retire or restructure the debt. Debt restructurings occur for $9 \%$ and $13 \%$ of the sample firms in years 1 and 2 , and $5 \%$ and $7 \%$ of the firms retire the debt. One of the sample firms reports that it issued equity to increase the funds available for dividend payments.

\section{Summary and Discussion}

Dividend covenant restrictions in debt contracts are designed to reduce potential conflicts of interest between bondholders and stockholders. These restrictions typically define funds available for dividend payments in terms of accounting earnings defined under GAAP.

26 Some conterence participants argued that managers of the sample firms chose to cut dividends rather than change accounting policies because dividend cuts are costless to the shareholders. However, a number of earlier studies show that dividend cuts are associaled with significant wealth losses for shareholders (see Dielman and Oppenheimer (1984), and Healy and Palepu (1988)). These wealth losses occur for our sample also. Firms that omit dividends have a $-7 \%$ two day abnormal stock return at the omission announcement; dividend decreases (excluding omissions) are accompanied by a $.3 \%$ iwo day abnormal announcement return. Presumably dividend covenants exist because bondholders believe that managers are reluctant to voluntarily reduce dividends given these wealth losses to shareholders.

27 Frequencies of liability restructurings are not reported by Accounting Trends and Techniques and are therefore not shown in Table 9. 

Since there is considerable accounting discretion available under GAAP, managers can potentially circumvent dividend covenant restrictions, and avoid dividend cuts by increasing earnings through accounting decisions. This paper provides evidence on this hypothesis by examining accounting and dividend policy changes in response to an increase in the probability of violating the dividend covenant restriction.

The results indicate that there are no significant changes in firms' accounting methods surrounding the increased tightness of the dividend constraint. While the sample firms adopt income-increasing pension accounting assumptions during the four years surrounding the nearviolation of the dividend constraint, they appear to be motivated by cash management considerations, rather than the increase in tightness of the dividend constraint. In contrast, in the year of the near-violation there is a substantial increase in the frequency of dividend cuts and omissions, persisting for several subsequent years. The magnitude of the dividend reductions is related to the degree of tightness of the dividend constraint. A small number of sample firms also restructure the debt that contains the binding dividend restriction. We therefore conclude that accounting decisions play only a limited role in sample firms' overall responses.

The high frequency of dividend covenants in debt contracts suggests that bondholders consider this conflict to be important, and believe that the firms' managers will not cut dividends to protect bondholders' interests without this covenant. Earlier studies raise questions about the effectiveness of these covenants given the accounting discretion available to managers. The findings of this study suggest that earnings-based dividend covenants are an effective means for bondholders 10 constrain firms' dividend policies. 

A number of bond covenant constraints other than the dividend restriction also use accounting variables. These can be classified into two categories: negative covenants, and affirmative covenants. Negative covenants, such as the dividend restriction examined in this paper, prevent managers from taking actions which transfer wealth from bondholders 10 stockholders. Affirmative covenants, such as working capital, interest coverage, and net worth covenants, are designed to increase the security of bondholders. Negative covenants violations can be avoided by taking actions which are managers control. For example, violation of the dividend covenant can be avoided by culting dividends, even though it is costly for shareholders. In contrast, avoiding violations of affirmative covenants usually requires the firm 10 improve its operating performance, which is not completely under managers' control. These constraints may therefore be more likely to trigger accounting responses than the dividend covenants examined in this paper. This is an interesting topic for future research. 



\section{References}

Belsley, D.A., E. Kuh, and R.E. Welsch, "Regression Diagnostics," (Wiley, New York, NY).

Bowen, R., E. Noreen, and J. Lacey, "Determinants of the Corporate Decision to Capitalize Interest," Journal of Accounting and Economics 3 (August 1981), pp. 151-179.

Daley, L.A., and R.L. Vigeland, "The Effects of Debt Covenants and Political Costs on the Choice of Accounting Methods: The Case of Accounting for R\&D Costs," Journal of Accounting and Economics 5 (December 1983), pp. 195-211.

Deakin, E.B., "An Analysis of Differences Between Non-Major Oil Firms Using Successful Efforts and Full Cost Methods," Accounting Review 54 (October 1979), pp. 722-734.

Dhaliwal, D., "The Effect of the Firm's Capital Structure on the Choice of Accounting Methods," Accounting Review 55 (January 1980), pp. 78-84.

Dhaliwal, D., G. Salamon, and E. Smith, "The Effect of Owner Versus Management Control on the Choice of Accounting Methods," Journal of Accounting and Economics 4, (July 1982), pp. 41-53.

Dielman T.E., and H. R. Oppenheimer, "An Examination of Investor Behavior During Periods of Large Dividend Changes," Journal of Financial and Quantitative Analysis, 1984, pp.197. 216.

Duke, J. C., and H. G. Hunt III, "An Empirical Examination of Debt Covenant Restrictions and Accounting-Related Debt Proxies," Journal of Accounting and Economics, (forthcoming).

Fama, E. F. and H. Babiak, "Dividend Policy: An Empirical Analysis," Journal of the American Statistical Association 63, (1968), pp. 1132-1161.

Healy, P.M. and K.G. Palepu, "Earnings Information Conveyed by Dividend Initiations and Omissions," Journal of Financial Economics, 21 (1988), pp.149-175.

Holthausen, R.W., "Evidence on the Effect of Bond Covenants and Management Compensation Contracts on the Choice of Accounting Techniques: The case of the Depreciation Switch Back," Journal of Accounting and Economics 3 (March 1981), pp.73-109.

Jensen, M.C., and W.H. Meckling, "Theory of the Firm: Managerial Behavior, Agency Costs and Ownership Structure," Journal of Financial Economics 3 (October 1976) pp. 305-360.

Kalay, A., "Stockholder-Bondholder Conflict and Dividend Constraints," Journal of Financial Economics 10 (July 1982), pp. 211-233.

Leftwich, R., Accounting Information in Private Markets: Evidence from Private Lending Agreements," Accounting Review 58 (January 1983) pp. 23-42. 

Lilien, S., M. Mellman, and V. Pastena, "Accounting Changes: Successful Versus Unsuccessful Firms," Accounting Review 63, (Oclober 1988), pp. 642.656.

Lilien, S., and V. Pastena, "Determinants of Intra-method Choice in the Oil and Gas Industry," Journal of Accounting and Economics 4 (December 1982), pp. 145.170.

Myers, S.C., "Determinants of Corporate Borrowing," Journal of Financial Economics 5 (November 1977) pp. 147-175.

Smith, C.W., and J.B. Warner, "On Financial Contracting: An Analysis of Bond Covenants," Journal of Financial Economics 7 (June 1979) pp. 117-161.

Watts, Ross and Jerold Zimmerman, "Positive Accounting Theory", Prentice Hall, Englewood Cliffs, NJ, 1986.

White, Halbert, "A Heteroskedasticity-consistent covariance matrix estimator and a direct test for heteroskedasticly, Econometrica 48, pp. 817-838. 



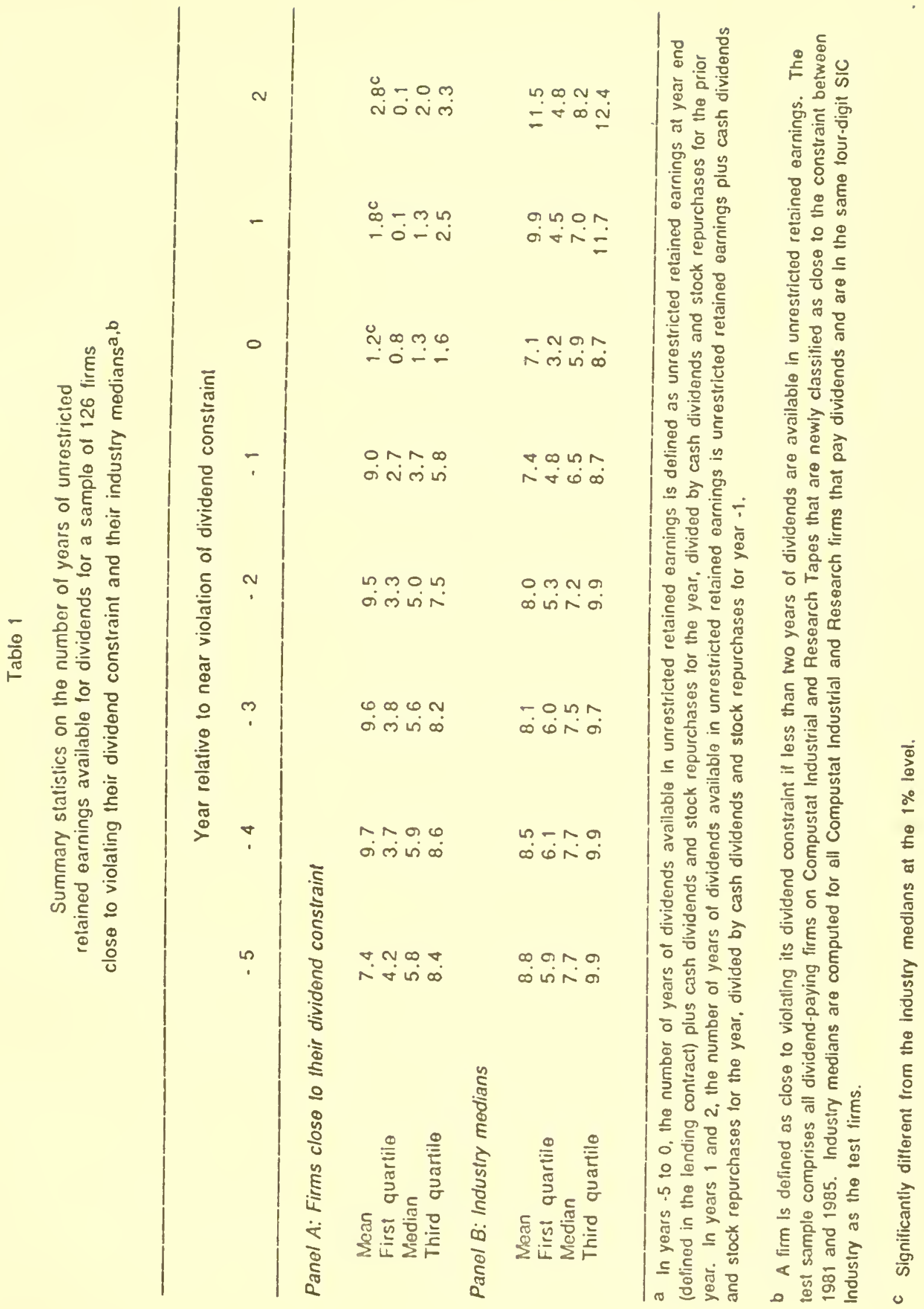



Table 2

Frequency of accounting procedures used by firms two years prior

to near-violation of their lending agreement dividend constrainta

Accounting

methods ${ }^{b}$
Frequency of accounting procedures used by

Accig. Trends \&

Test sample
Techniques sample

\section{Depreciation Method}

Straight-line

Accolerated method

$93.7 \%$

$93.6 \%$

Units of production

$18.3 \mathrm{c}$

25.9

Other

$15.9 c$

0.0

9.1

0.4

Inventory pricing

LIFO

FIFO

$58.7^{c}$

57.9

66.3

$21.4^{c}$

62.9

Average cost

Other

7.9

39.8

9.1

Use of LIFO

All inventories

$16.2^{c}$

6.5

$50 \%$ or more of inventories

$37.8^{c}$

51.1

Less than $50 \%$ of inventories

24.4

21.6

23.2

Not determinable

$94.4^{c}$

88.8

7.9

10.2

Delerral

No relerence 10 Investment Tax Credit

0.0

1.1

Amortization of Intangibles

40 years

40.5

6.3

37.4

10.30 years

$10.3 c$

2.7

Other

$42.9^{c}$

5.2

54.7

Amortizalion of Prior Period Service Cost

40 years

$30-40$ years

13.5

12.7

20.6

17.5

10.30 years

17.5
4.8

30.9

No pension plan or prior period servica cost reported

Pension Rate of Relurn

$6 \%$ or less

$6.1 \% \cdot 7 \%$

13.5

19.1

25.4

$7.1 \% \cdot 8 \%$

13.5

Other

Not reported or no pension plan

a A firm is defined as close 10 violaling its dividend constraint II less than two years of dividends are available in unresiricled relained earnings. The test sample comprises 126 firms that are newly classified as close 10 the consiraint between 1981 and 1985.

- The irequencies lor depreciation, inventory, and invesiment lax credil do nol edd $10100 \%$. since some firms use more than one melhod.

c Significanlly dilieren! from the frequency for Accounling Trends and Techniques sample at the $5 \%$ level using a iwo-lailed Binomial lest. 

Table 3

Frequency of accounting procedure changes by year for 126 firms close to violating their lending agreement dividend constraint.

Accounting Trends and Techniques' frequencies in parentheses a

\begin{tabular}{|c|c|c|c|c|}
\hline \multirow{2}{*}{$\begin{array}{l}\text { Accounting } \\
\text { procedure. } \\
\text { change }\end{array}$} & \multicolumn{4}{|c|}{ Year relative to near violation of dividend constraint } \\
\hline & -1 & 0 & 1 & 2 \\
\hline \multicolumn{5}{|c|}{ Panel A. Voluntary Changes: } \\
\hline $\begin{array}{l}\text { Pension assumplions } \\
\text { and/or cosl melhod }\end{array}$ & $\begin{array}{l}14.2 \% \\
(20.6)\end{array}$ & $\begin{array}{l}33.3 \% b \\
(23.4)\end{array}$ & $\begin{array}{l}36.8 \% b \\
(21.0)\end{array}$ & $\begin{array}{l}27.2 \% \\
(20.9)\end{array}$ \\
\hline LIFO adopted or extended & $\begin{array}{l}0.8 \\
(3.5)\end{array}$ & $\begin{array}{l}2.4 \\
(2.1)\end{array}$ & $\begin{array}{l}0.9 \\
(1.2)\end{array}$ & $\begin{array}{c}1.1 \\
(2.9)\end{array}$ \\
\hline Other inventory changes & $\begin{array}{l}0.0 \\
(1.0)\end{array}$ & $\begin{array}{l}0.8 \\
(1.2)\end{array}$ & $\begin{array}{l}0.9 \\
(1.0)\end{array}$ & $\begin{array}{l}2.2 \\
(1.0)\end{array}$ \\
\hline Depreciation method & $\begin{array}{l}0.8 \\
(1.3)\end{array}$ & $\begin{array}{l}0.8 \\
(1.3)\end{array}$ & $\begin{array}{l}0.0 \\
(0.9)\end{array}$ & $\begin{array}{c}1.1 \\
(0.8)\end{array}$ \\
\hline Depreciable lives & $\begin{array}{l}0.0 \\
(0.4)\end{array}$ & $\begin{array}{l}0.8 \\
(0.6)\end{array}$ & $\begin{array}{l}0.9 \\
(0.7)\end{array}$ & $\begin{array}{l}0.0 \\
(0.6)\end{array}$ \\
\hline Investment credit & $\begin{array}{l}0.8 \\
(0.8)\end{array}$ & $\begin{array}{l}0.0 \\
(0.8)\end{array}$ & $\begin{array}{l}0.0 \\
(0.4)\end{array}$ & $\begin{array}{l}0.0 \\
(0.3)\end{array}$ \\
\hline \multicolumn{5}{|c|}{ Panel B. Mandalory Changes: } \\
\hline SFAS 43 adopted & $\begin{array}{l}8.7 \\
(9.0)\end{array}$ & $\begin{array}{l}8.1 \\
(6.2)\end{array}$ & $\begin{array}{c}0.9 \\
(1.6)\end{array}$ & $\begin{array}{l}0.0 \\
0.0\end{array}$ \\
\hline SFAS 52 adopted & $\begin{array}{l}14.2 \\
(13.9)\end{array}$ & $\begin{array}{l}11.4 \\
(11.8)\end{array}$ & $\begin{array}{l}6.0 \\
(8.9)\end{array}$ & $\begin{array}{l}3.3 \\
(3.3)\end{array}$ \\
\hline SFAS 87 adopted & $\begin{array}{l}0.0 \\
(0.0)\end{array}$ & $\begin{array}{l}0.0 \\
(0.6)\end{array}$ & $\begin{array}{c}9.4 \\
(9.1)\end{array}$ & $\begin{array}{c}6.5 \\
(8.8)\end{array}$ \\
\hline
\end{tabular}

a A firm is defined as close 10 violating its dividend constraint if less than two years of dividends are available in unrestrieted retained earnings. The test sample comprises 126 firms that are newly classitied as close to the constraint between 1981 and 1985 .

b Significantly different from the frequency for Accounting Trends and Techniques sample at the $5 \%$ level using a two-tailed Binomial test. 

Table 4

Summary statistics on type and magnitude of pension accounting changes for 126 firms $\operatorname{clos} \theta$ to violating their lending agreement dividend constraint ${ }^{a}$

Year relative to near violation of dividend constraint
$\cdot 1$
0
1
2

Panel A: Frequency of types of pension accounting changes

Changes in rate of return assumplions

Reduction

No change

Increase less than $1 \%$

Increase between 1 and $2 \%$

Increase greater than $2 \%$
$0.0 \%$

91.2

6.4

0.8

1.6
$3.3 \%$

69.4

17.4

7.4

2.5
$8.7 \%$

74.8

11.3

3.5

1.7
$6.4 \%$

75.3

8.6

5.4

4.3

changes in actuarial assumptions

$\begin{array}{lcccc}\text { Change } & 7.2 \% & 6.7 \% & 9.6 \% & 4.3 \% \\ \text { No change } & 92.8 & 93.3 & 90.4 & 95.7\end{array}$

Changes in amortization period for prior service cosls

$\begin{array}{lcccc}\text { Decrease } & 0.8 \% & 0.0 \% & 4.4 \% & 2.1 \% \\ \text { Nochange } & 98.4 & 99.2 & 94.8 & 97.9 \\ \text { Increase } & 0.8 & 0.8 & 0.9 & 0.0\end{array}$

Panel B: Income effecl of pension changes relative to year -1 dividends

Eirms changing pension accounting procedures $b$

$\begin{array}{lcccc}\text { Mean } & 0.09 & 0.34 & 0.18 & 0.08 \\ \text { Median } & 0.06 & 0.00 & 0.00 & 0.00 \\ \text { Number of observations } & 18 & 42 & 46 & 34\end{array}$

Firms disclosino material earnings effects of pension chanoes

$\begin{array}{lcccc}\text { Mean } & 0.12 & 0.83 & 0.35 & 0.21 \\ \text { Median } & 0.08 & 0.09 & 0.16 & 0.13 \\ \text { First quartile } & 0.05 & 0.05 & 0.05 & 0.04 \\ \text { Third quartile } & 0.15 & 0.64 & 0.50 & 0.25 \\ \text { Number of observations } & 13 & 17 & 23 & 13\end{array}$

- A firm is defined as close to violating its dividend constraint if less than two years of dividends are available in unrestricted retained earnings. The test sample comprises 126 firms that are newly classified as close to the constraint between 1981 and 1985.

- The earnings effect of the change in pension accounting method is assumed to be zero for firms that repon the effect as immaterial. 



\section{Table 5}

Tests of the relation between earnings effects of changes in pension accounting policies, and the closeness to dividend constraints after controlling for changes in operating cash flows for firms that are close to violating their dividend constraint and make pension acoounting changes a

$$
P E F F_{j t}=B_{0}+B_{1} \Delta C F_{j t}+B_{2} D R_{j t}+\varepsilon_{j t}{ }^{b}
$$

\begin{tabular}{lcccc} 
& $B_{0}$ & $B_{1}$ & $B_{2}$ & $R^{2}$ \\
\hline Coefficient & 0.80 & -0.025 & -0.030 & 0.05 \\
t statistic & $(2.5)$ & $(-2.0)$ & $(-0.4)$ & \\
\hline
\end{tabular}

a A firm is detined as close to violating its dividend constraint if less than two years of dividends are available in unrestricted retained earnings. Obsevations are for firm-years where there are pension accounting changes (140 firm-years in total).

b PEFF $\mathrm{Jt}_{\mathrm{f}}$ is the change in net income per share from the pension accounting change as a percentage of the beginning of year stock price: $\triangle C F_{\mathrm{jt}}$ is the change in operating cash llow per share for firm $\}$ in year 1 before the elfect of the pension change as a percentage of the beginning of year stock price: $D R_{j t}$ is the number of years of unrestricted retained earnings available for dividends for firm $j$ in year $t$. 



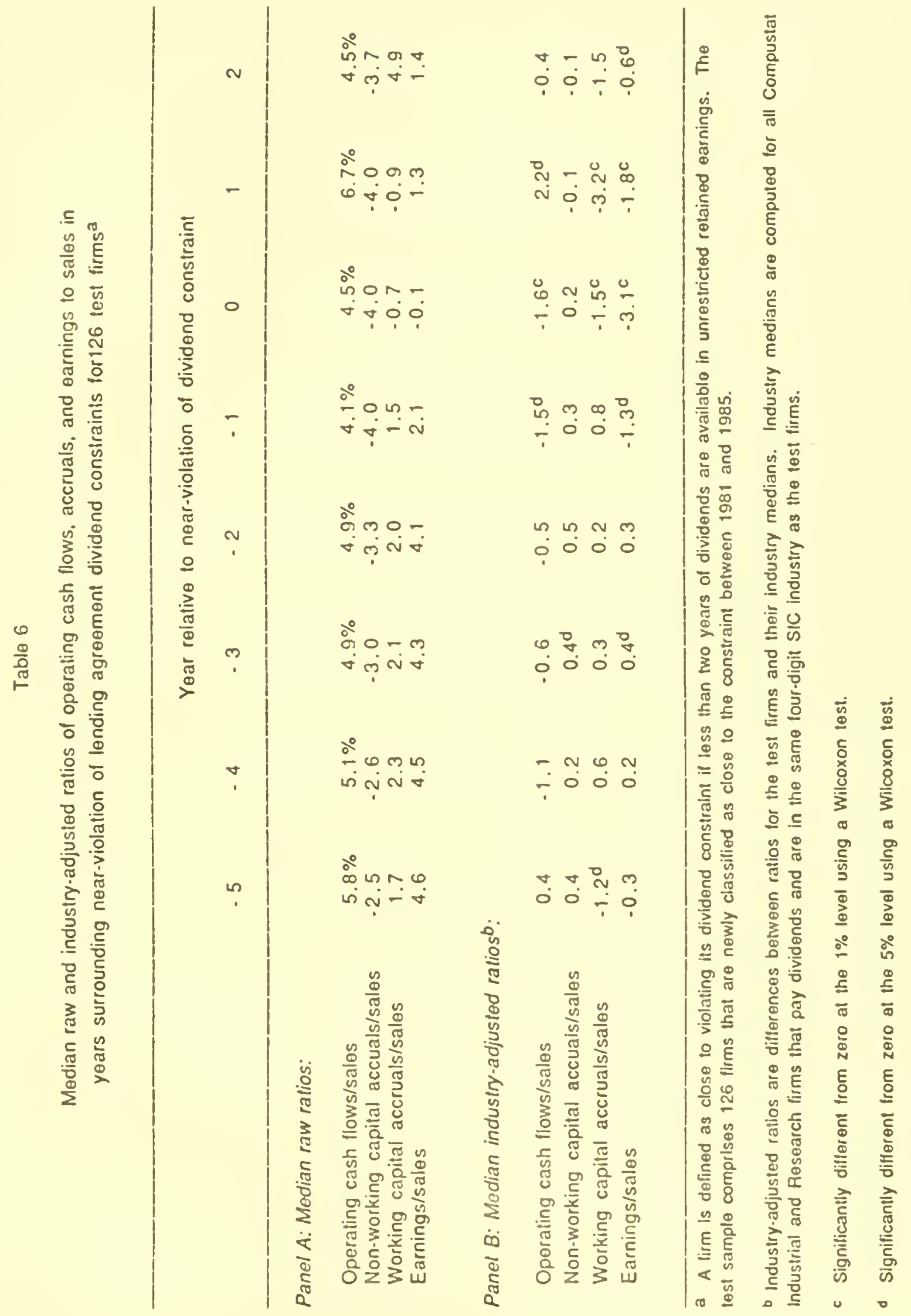




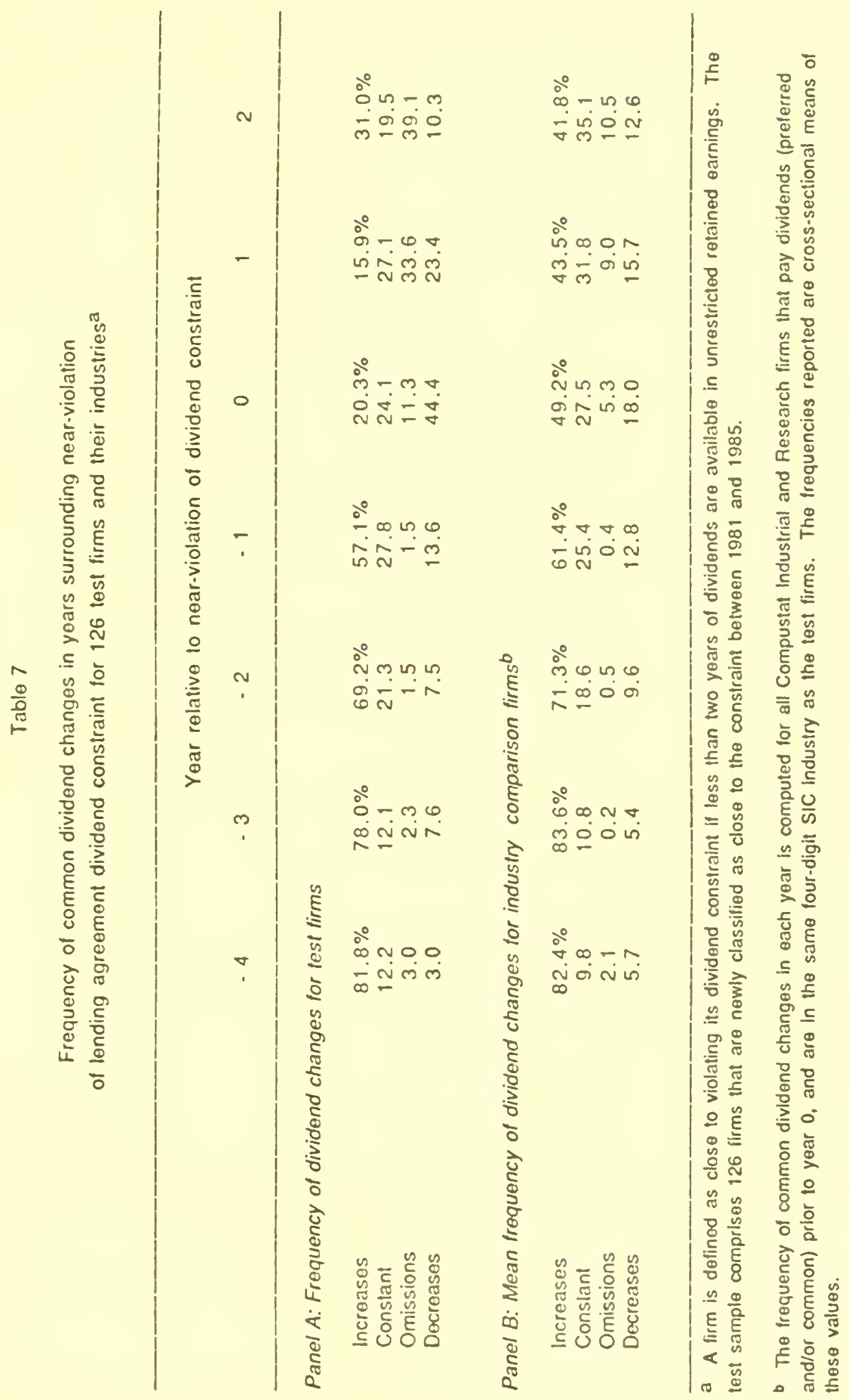



Table 8

Tests of the relation between changes in dividends, and the closeness to dividend constraints atter controlling tor changes in earnings tor a sample

of 126 firms that are close to violating their dividend constraint ${ }^{a}$

Equation 2: $\triangle O I V_{j t}=B_{0}+B_{1} \Delta E A R N_{j t}+B_{2} D R_{j l}+c_{j t}$

$\begin{array}{lrr}B_{0} & -0.600 & -8.1 \\ B_{1} & 0.014 & 4.5 \\ B_{2} & 0.100 & 9.2 \\ R^{2} & 0.13 & \end{array}$

Equation 3: $\triangle D I V_{j l}=B_{O}+B_{1 j} \Delta E A R N_{j t}+B_{2} D R_{j t}+\varepsilon_{j t} b^{b}$

$\begin{array}{lcc}B_{0} & -0.500 & -6.9 \\ \text { Mean } B_{1 j} & 0.017 c & \\ \text { Median } B_{1 j} & 0.012 & \\ B_{2} & 0.090 & 8.0 \\ R^{2} & 0.40 & \end{array}$

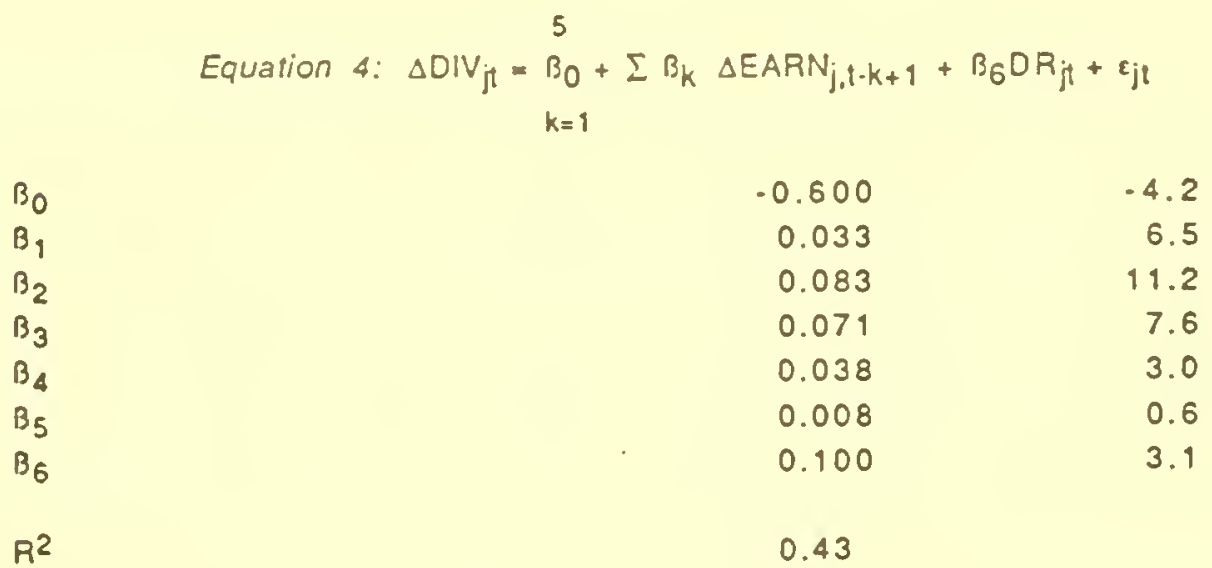

a A firm is delined as close to violating its dividend constraint if less than two years of dividends are available in unrestricted retained eamings The test sample comprises all dividend.paying firms on Compustat Industrial and Research Tapes that are nowly classified as close to the constraint between 1981 and 1985.

b $\triangle D I V_{j t}$ is the change in dividends per share as a percent of beginning of period slock price for firm $j$ in year $t \quad t=-5$ 102 ): $\triangle E A R N_{j} t$ is the change in eamings per share as apercent of beginning of period slock price for firm $f$ in year $t$. $D R_{j t}$ is the number of years of unrestricted retained earnings available for dividends firm I In year $t$.

c An $F$ statistic is used to iest whether $B_{1 j}$ are jointly zero for the sample firms. The estimated $F$ statistic (dt 1,1 ) is 63.6, and is significant at the $1 \%$ level. 

Table 9

Frequency of liability restructurings by year for 126

firms close to violating their lending agreement dividend constrainta

Year relative to near violation of dividend constraint

$\begin{array}{llll}-1 & 0 & 1 & 2\end{array}$

\begin{tabular}{|c|c|c|c|c|}
\hline Waiver of covenants & $3.3 \%$ & $6.5 \%$ & $4.3 \%$ & $1.1 \%$ \\
\hline Retirement of debt & 0.0 & 0.0 & 5.1 & 6.6 \\
\hline $\begin{array}{l}\text { Restructuring of debt or amer } \\
\text { of lending agreement }\end{array}$ & 1.1 & 1.6 & 8.6 & 13.2 \\
\hline Issue equity to pay dividends & e. & el & 1.7 & 0.0 \\
\hline Total & 4.4 & 8.1 & 19.7 & 20.9 \\
\hline
\end{tabular}

a A firm is defined as close to violating its dividend constraint if less than two years of dividends are available in unrestricted retained earnings. The sample comprises 126 firms that are newly classified as close to the constraint between 1981 and 1985 . 

Figure 1

Number of years of unrestricted retained earnings available for dividends and frequency of dividend cuts and omissions, and in years surrounding nearviolation of dividend covenant for 126 firms

Panel A: Number of years of unrestricted retained earnings available for dividends

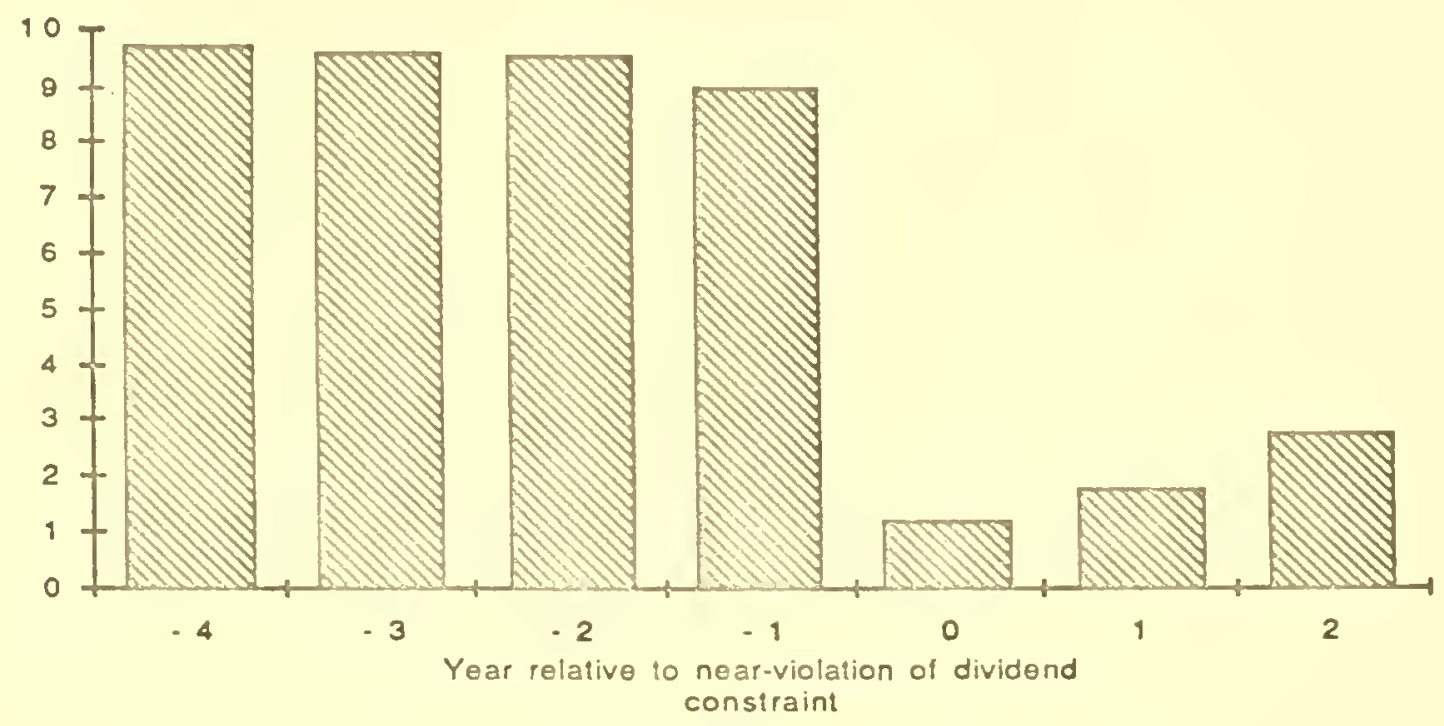

Panel B: Frequency of dividend cuts and omissions

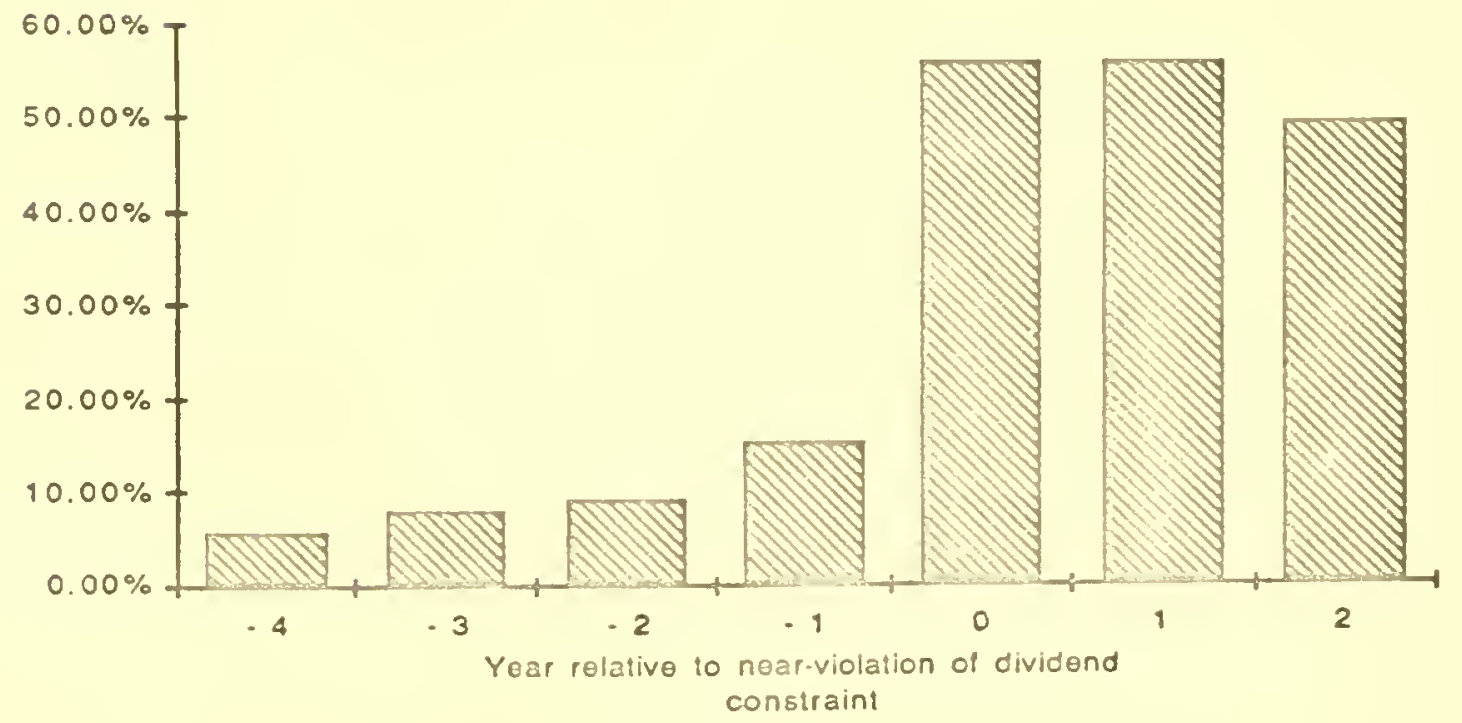





$$
1077 \quad 47
$$





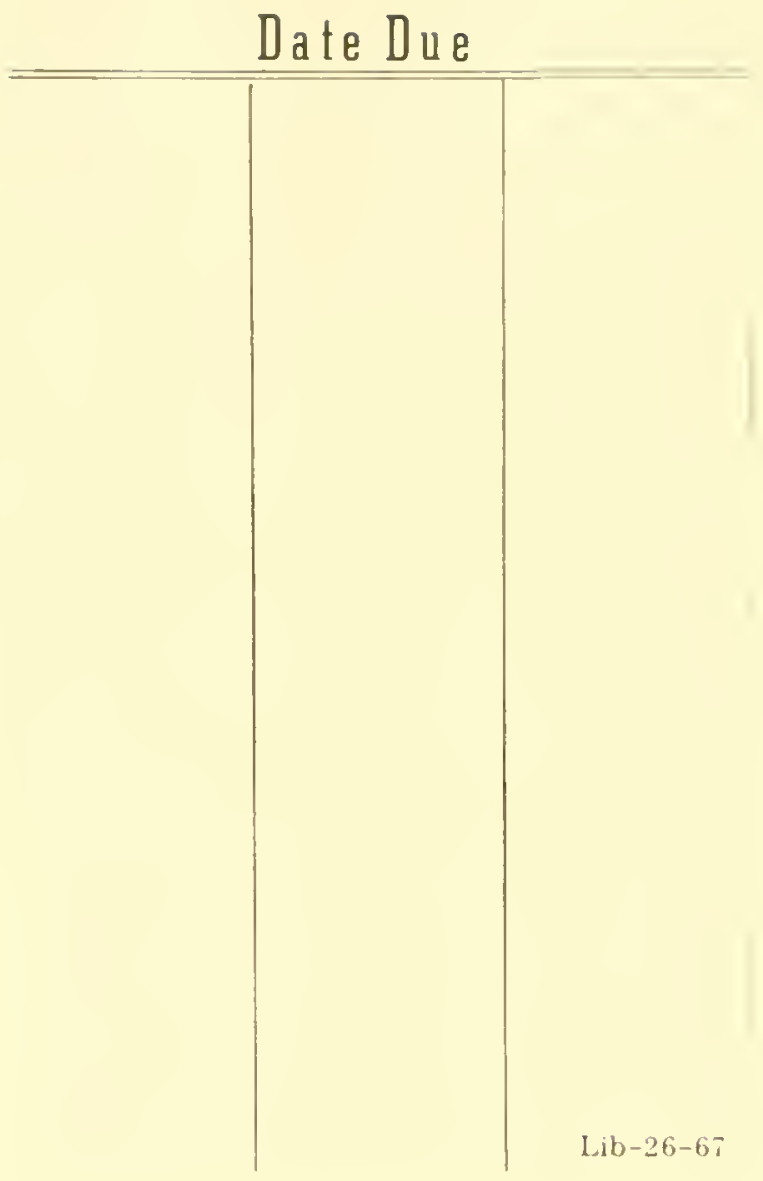




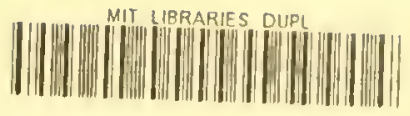

$39080 \quad 007287953$ 
